\title{
The Hydrogen Ion Concentration in the Gut of certain Lamellibranchs and Gastropods.
}

\author{
By \\ C. M. Yonge, B.Sc., Ph.D., \\ Temporary Assistant Naturalist at the Plymouth Laboratory.
}

So far as I am aware, no accurate estimations of the hydrogen ion concentration in the alimentary tract of the Mollusca have been made; we only know that the fluid in the gut usually gives an acid reaction to litmus and similar indicators. In this paper I have estimated the $\mathrm{pH}$ of the various regions of the gut in a number of typical Lamellibranchs and Gastropods. Clarke and Lubs' indicators were used, being mixed with the fluid or tissue to be tested on a white plate and the colours compared with those of the same indicators added to drops of standard solutions of known $\mathrm{pH}$ value; the usual corrections for salt error were made. I have also attempted to determine, as far as possible, the causes of the prevailing acidity of the gut, and also some of its effects, particularly on the permanence of the style and on the action of the cilia of the gut.

This research was carried out at the Plymouth Laboratory during the winter of 1924-25, while I was holding a Carnegie Research Scholarship of the University of Edinburgh. I wish to thank the British Association, the University of London, and the Royal Microscopical Society for granting me the use of their tables for various periods, and the Director and staff of the Laboratory for their kindness and help.

\section{LAMELLIBRANCHIA.}

Hydrogen Ion Concentration in the Gut.

Three species were chosen for examination on account of their large size, namely, Pecten maximus, Mya arenaria and Ensis siliqua. Table I shows the $\mathrm{pH}$ value of the contents of the gut, of the crystalline style and of the tissue of the digestive gland in these animals.

The stomach is in all cases the most acid region of the gut (in Ensis the œsophagus gives the same value, but this is probably due to fluid from the stomach), after which the $\mathrm{pH}$ rises along the mid-gut and rectum. The same results were obtained whether the animals examined were freshly fed or starved, which shows that there is no outpouring of acid secretion in response to the entrance of food into the gut. 
The most acid substance in the gut is the style, and this is responsible for the acid reaction throughout the alimentary tract. Hitherto the digestive gland has been regarded as the source of the acidity of the gut in the Lamellibranchs, an opinion which I held myself at the time of my earlier work on Mya (Yonge (12)) ; but, as a result of further work and investigation of literature, I have been led to the conclusion that

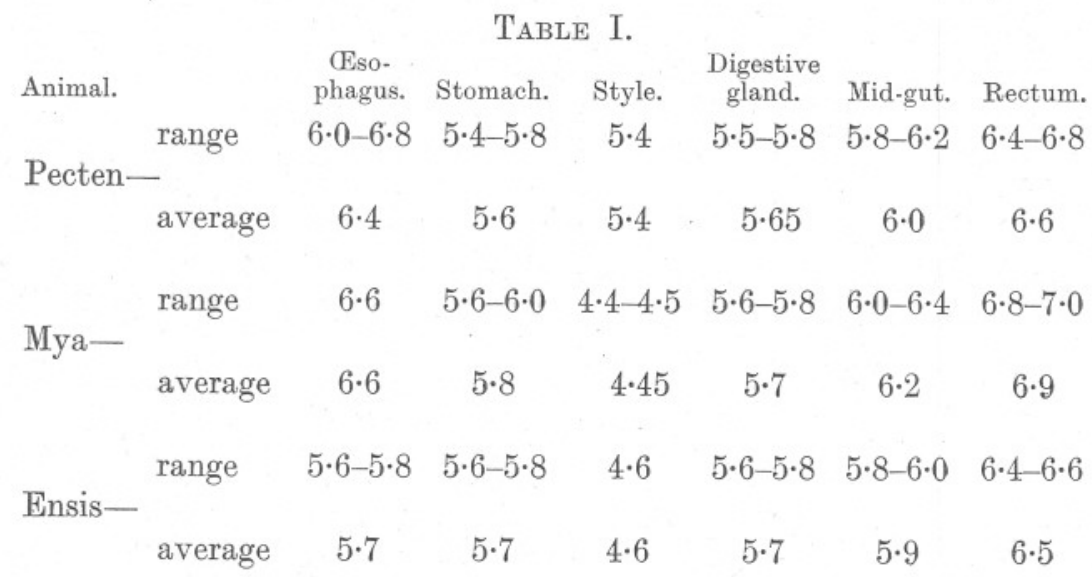

the digestive gland in the Lamellibranchs (with the possible exception of the Septibranchiata, which I have not as yet been able to examine) is purely an absorptive, and not a secretory, organ.

If the digestive gland does not secrete, and since there are no salivary glands, the origin of the acidity of the gut must be the style. This is secreted in a special groove in the mid-gut in Pecten, and in a separate cæcum in Mya and Ensis. In order to determine whether the $\mathrm{pH}$ of the gut rose in their absence, the styles were removed from eight living Mya (by the method used by Edmondson (4)), which were then replaced in sea water. Four of the animals recovered from the operation, and, after five days, these were opened and the $\mathrm{pH}$ of their guts estimated, with the results shown in Table II.

\begin{tabular}{|c|c|c|c|c|c|c|c|}
\hline \multicolumn{8}{|c|}{ TABLE II. } \\
\hline Mya number:- & & & 1 & 2 & 3 & 4 & Average. \\
\hline Esophagus . & . & . & $6 \cdot 8$ & $6 \cdot 4$ & $6 \cdot 6$ & $6 \cdot 9$ & $6 \cdot 67$ \\
\hline Stomach . & . & . & $6 \cdot 4$ & $6 \cdot 4$ & $6 \cdot 6$ & $6 \cdot 9$ & $6 \cdot 625$ \\
\hline Style Sac & $\cdot$ & . & $5 \cdot 8$ & $6 \cdot 1$ & $5 \cdot 8$ & $6 \cdot 0$ & $5 \cdot 9$ \\
\hline Digestive Gland & . & . & $5 \cdot 6$ & $5 \cdot 8$ & $5 \cdot 7$ & $5 \cdot 7$ & $5 \cdot 7$ \\
\hline Mid-Gut & . & . & $6 \cdot 4$ & $6 \cdot 4$ & $6 \cdot 2$ & $6 \cdot 4$ & $6 \cdot 45$ \\
\hline
\end{tabular}

Rectum . . Too little fluid to estimate. 
Whereas the average values for the œsophagus and the digestive gland remained practically unchanged, the $\mathrm{pH}$ of the stomach showed a rise of 0.825 , and that of the mid-gut a rise of 0.25 . In no case was there any sign of a new style - which was hardly to be expected since Edmondson found that Mya takes seventy-four days completely to regenerate the style after it has been removed-but such fluid as was present in the empty style sac had a $\mathrm{pH}$ of $5 \cdot 9$, the result, presumably, of the acid secretion of the epithelium. The average $\mathrm{pH}$ of the sea water in the mantle cavities of the four animals was $7 \cdot 1$, and the reduction from this to the 6.625 of the stomach can be accounted for entirely by the entrance of the fluid from the style sac and by a certain excretion of $\mathrm{CO}_{2}$ from the

TABLE III.

\begin{tabular}{rccc} 
No. & Condition of Style. & $\mathrm{pH}$ in Stomach. & $\mathrm{pH}$ in Mantle Cavity. \\
1. & Absent & $6 \cdot 5$ & $7 \cdot 2$ \\
2. &, & $6 \cdot 8$ & $7 \cdot 2$ \\
3. & " & $6 \cdot 7$ & $7 \cdot 2$ \\
4. & $"$ & $6 \cdot 4$ & $7 \cdot 2$ \\
5. & $"$ & $6 \cdot 8$ & $7 \cdot 2$ \\
6. & " & $6 \cdot 6$ & $7 \cdot 2$ \\
7. & Traces & $6 \cdot 7$ & $7 \cdot 2$ \\
8. & Absent & $6 \cdot 2$ & $7 \cdot 1$ \\
9. &, & $6 \cdot 6$ & $7 \cdot 0$ \\
10. & Traces & $6 \cdot 4$ & $7 \cdot 1$ \\
11. & & $6 \cdot 5$ & $7 \cdot 1$ \\
12. & & $6 \cdot 3$ & $7 \cdot 3$ \\
\multicolumn{2}{r}{ Average $=6 \cdot 54$} & $7 \cdot 17$
\end{tabular}

walls of the gut, which possibly possesses a slight respiratory function. The presence of $\mathrm{CO}_{2}$ is frequently indicated by a rise in $\mathrm{pH}$ after exposure to the air for a few minutes. There is no need, therefore, to postulate the presence of an acid secretion from the digestive gland, although there is an excretion into the gut of the indigestible remnants of intracellular digestion which probably have an acid reaction, and may influence the $\mathrm{pH}$ of the gut to a slight extent.

It is well known that, under certain circumstances, the style is very readily dissolved and reformed in many Lamellibranchs in which it lies free in the mid-gut and is not enclosed in a separate cæcum. If the style is, indeed, the source of the acidity of the gut, it would naturally be expected that the $\mathrm{pH}$ of the stomach would be higher in animals of this type when the style is absent than when it is present. Accordingly, 
experiments were performed on Mytilus edulis, Tapes pullastra, and Pecten maximus to discover whether this is the case.

Twenty-five healthy Mytilus, taken straight from the sea, were opened and the $\mathrm{pH}$ of the stomach contents determined. The average value for the twenty-five came to $6 \cdot 08$, and the average for the $\mathrm{pH}$ of the water in the mantle cavity to $7 \cdot 4$. A firm, fully developed style was present in every one of these animals. Since it has frequently been observed that in Mytilus the style dissolves when the animal is kept out of water, twelve specimens were placed in a cool dry place for four days, and were then opened and the condition of the style and the $\mathrm{pH}$ of the contents of the stomach and of the mantle cavity determined, with the results shown in Table III.

Although the twelve animals remained perfectly healthy, the style was absent in all but two cases, when slight traces were still present. The average value for the $\mathrm{pH}$ of the fluid in the mantle cavity was $7 \cdot 17$, a fall of $0 \cdot 23$, yet the average for the stomach had risen by $0 \cdot 46$ to $6 \cdot 54$.

Berkeley (2) found that the styles of Saxidomus giganteus and Paphia staminea disappeared when these animals were kept under anaerobic conditions, but reformed when they were returned to normal aerobic conditions. Accordingly, seven Mytilus were kept for six days in a sealed jar containing sea water from which the oxygen had largely been withdrawn in vacuo, and a similar number in boiled sea water. Both these jars were placed in the tanks of circulating water to keep them under normal conditions of temperature. Table IV gives the results of the two experiments.

\section{TABLE IV.}

\begin{tabular}{|c|c|c|c|c|c|}
\hline \multicolumn{3}{|c|}{ Six days in Boiled Sea Water. } & \multicolumn{3}{|c|}{ Six days in Deoxygenated Sea Water. } \\
\hline No. & Style. & $\mathrm{pH}$ in Stomach. & No. & Style. & $\mathrm{pH}$ in Stomach. \\
\hline 1. & Absent & $6 \cdot 8$ & 1. & Absent & $6 \cdot 6$ \\
\hline 2. & , & $6 \cdot 8$ & 2. & , & $6 \cdot 4$ \\
\hline 3. & , & $6 \cdot 6$ & 3. & , & $6 \cdot 5$ \\
\hline 4. & , & $6 \cdot 5$ & 4. & , & $6 \cdot 2$ \\
\hline 5. & , & $6 \cdot 4$ & 5. & , & $6 \cdot 3$ \\
\hline 6. & , & $6 \cdot 3$ & 6. & Traces & $6 \cdot 0$ \\
\hline 7. & Traces & $6 \cdot 1$ & 7 . &, & $6 \cdot 1$ \\
\hline
\end{tabular}

The style was absent in eleven out of the fourteen animals, and the average value for the $\mathrm{pH}$ in the stomach in these animals was 6.49 as compared with 6.07 for the three cases in which the style was still present.

The most satisfactory method for ensuring the dissolution of the style was suggested to me by Dr. J. H. Orton, and consisted of clamping the 
shell valves together and then replacing the animals in the tanks. Fifteen animals were treated in this way and left for seven days. Ten of these contained no style, and had an average value for the $\mathrm{pH}$ of the stomach of 6.49 and for the water in the mantle cavity of $7 \cdot 2$. Altogether, therefore, the average value for the $\mathrm{pH}$ of the fluid in the stomach in the thirtyone Mytilus which contained no style came to 6.53 and for the fluid in the mantle cavity to $7 \cdot 2$, compared with $6 \cdot 08$ and $7 \cdot 4$ respectively in the case of the fresh animals which all contained styles. Thus, in spite of the fact that the $\mathrm{pH}$ of the mantle cavity dropped by $0 \cdot 2$, the $\mathrm{pH}$ in the stomach rose by $0 \cdot 45$.

Similar experiments were carried out with Tapes pullastra, seven animals being clamped for seven days, and the results compared with those obtained from seven unclamped animals which had been lying side by side in the tanks with them. Table $\mathrm{V}$ shows the results obtained.

\section{TABLE V.}

\begin{tabular}{|c|c|c|c|c|c|}
\hline \multicolumn{3}{|c|}{ Not Clamped. } & \multicolumn{3}{|c|}{ Clamped for Seven Days. } \\
\hline No. & Style. & $\mathrm{pH}$ in Stomach. & No. & Style. & $\mathrm{pH}$ in Stomach. \\
\hline 1. & Present & $6 \cdot 2$ & 1. & Absent & $6 \cdot 9$ \\
\hline 2. & , & $6 \cdot 2$ & 2. & , & $6 \cdot 9$ \\
\hline 3. & , & $6 \cdot 2$ & 3. & , & $6 \cdot 6$ \\
\hline 4. & , & $5 \cdot 9$ & 4. & , & $6 \cdot 7$ \\
\hline 5. & , & $5 \cdot 8$ & 5. & , & $6 \cdot 7$ \\
\hline 6. &, & $5 \cdot 8$ & 6. & , & $6 \cdot 7$ \\
\hline 7 . & ", & $6 \cdot 0$ & 7. & $"$ & $6 \cdot 6$ \\
\hline & $\mathrm{Al}$ & age $=\overline{6 \cdot 01}$ & & & age $=\overline{6 \cdot 73}$ \\
\hline
\end{tabular}

The results of this experiment are still more convincing. No trace of a style was present in any of the clamped animals, and the difference in the average values of the $\mathrm{pH}$ of the contents of the stomach in the two series amounted to no less than $0 \cdot 72$.

Pecten maximus was treated in the same way; but, though similar results-disappearance of the style and an increase in the $\mathrm{pH}$ of the contents of the stomach-were obtained in several cases, these animals are not at all suited to this treatment and many died.

From the results of the foregoing experiments, there can be little doubt that the acidity of the gut in the Lamellibranchs is due to the presence of the crystalline style since, when that is absent, there is a pronounced increase in the $\mathrm{pH}$ of the gut, even though the $\mathrm{pH}$ of the water in the mantle cavity has fallen. 


\section{Permanence of the Style.}

The cause of the rapid dissolution of the style has always been a disputed point. Hazay $(\boldsymbol{(})$ and Haseloff $(\mathbf{6})$ based their theory that the style is a reserve of food upon the observed fact that it was absent in animals that had been starved, but was reformed when they were fed. Allen (1) and Dakin (3) state that the styles of Anodonta and Pecten are absent or present under the same conditions. Nelson (10) is also of the opinion that the "style is a structure intimately connected with the feeding activities of the mollusc." . . . "Absence of food or inactivity of the animal due to cold or adverse conditions bring about a gradual dissolution of the style." Orton (11) found by experiment that the style of Ostrea is dissolved when the animal is removed from water; but that the speed with which it dissolves, and also with which it is reformed when it is returned to water, depends upon the physical condition of the animal, of which the colour and condition of the "liver" are the best criterion. As long as the animals were in good condition starvation had no effect on the presence of the style. Berkeley (2) found that the presence of the style was quite independent of the food supply, but that it depended on the supply of oxygen, and, since he found an oxidase in the style substance, he advances the opinion that the style is a reserve of oxidase, which is used up when the animal experiences anaerobic conditions.

In my earlier paper, in order to account for the fact that the style is only dissolved in those species in which it lies free in the mid-gut, I suggested that it was dissolved by the proteolytic enzyme secreted by the digestive gland. In view of further, and contradictory, evidence, I have abandoned this theory; but, as I had also found that the style dissolves more easily in an alkaline than an acid medium, I thought it possible that valuable information might be obtained by extending these experiments. Accordingly, styles were extracted from Ensis, Mya, Pecten and Mytilus (i.e. two animals in which the style lies in a separate cæcum, and two in which it lies free in the mid-gut), and, after having been measured, they were placed in tubes containing about 10 c.c. of standard buffer solutions, a little toluol being added to prevent decomposition. The time which the styles took to dissolve was noted, the results being given in Table VI.

The results show that the styles are dissolved rapidly in alkaline media, but more and more slowly as the medium becomes more acid, until at a certain point they cease to be dissolved. The substance of the style is a protein of a globulin nature, and so an amphoteric substance with an isoelectric point, and, judging by the above results, it appears to be soluble above the isoelectric point, but insoluble below it. This, apparently, is not the same for all four styles, those of Ensis and Mya 
having their isoelectric point at about $4 \cdot 4$ and $4 \cdot 2$ respectively, while in the case of Pecten and Mytilus it is decidedly lower, at about 3.6 in each. There is also, it will be noted, a difference in the $\mathrm{pH}$ of the style in the two types, those of Ensis and Mya being 4.45 and 4.6 respectively, and those of Pecten and Mytilus being both 5*4. Presumably these differences in physical properties are a result of the different conditions under which the two types of style are secreted.

The important point to be noted is that the style or, in the case of those which lie in a separate cæcum, the head of the style is normally surrounded by a fluid whose $\mathrm{pH}$-at lowest $5 \cdot 6$-is always high enough to enable it to dissolve the style. The style, therefore, can only be maintained so long as new substance is secreted and added to the hinder end

TABle VI.

\begin{tabular}{|c|c|c|c|c|}
\hline \multirow{2}{*}{$\mathrm{pH}$} & Mya. & Ensis. & Pecten.' & Mytilus. \\
\hline & $\begin{array}{c}\text { Length of Time to } \\
\text { Style. dissolve. }\end{array}$ & $\begin{array}{c}\text { Length of Time to } \\
\text { Style. dissolve. }\end{array}$ & $\begin{array}{l}\text { Length of Time to } \\
\text { Style. dissolve. }\end{array}$ & $\begin{array}{c}\text { Length of Time to } \\
\text { Style. }\end{array}$ \\
\hline $\begin{array}{l}9 \cdot 6 \\
8 \cdot 0 \\
7 \cdot 2 \\
6 \cdot 0 \\
5 \cdot 4 \\
5 \cdot 0 \\
4 \cdot 4 \\
4 \cdot 2 \\
4 \cdot 0 \\
3 \cdot 6 \\
3 \cdot 0 \\
2 \cdot 2\end{array}$ & $\begin{array}{lrl}4.3 \mathrm{~cm} . & 12 & \text { hrs. } \\
4.4 \mathrm{~cm} . & 21 & \text { hrs. } \\
3.8 \mathrm{~cm} . & 2 & \text { days. } \\
4.6 \mathrm{~cm} . & 2 & \text { days. } \\
4.5 \mathrm{~cm} . & 3 & \text { days. } \\
4.8 \mathrm{~cm} . & 6 & \text { days. } \\
3.8 \mathrm{~cm} . & 19 & \text { days. } \\
6.0 \mathrm{~cm} . & \text { Not dis. } \\
4.5 \mathrm{~cm} . & \text { ", } \\
4.4 \mathrm{~cm} . & \text { ", } \\
4.3 \mathrm{~cm} . & , \\
5.1 \mathrm{~cm} . & ,\end{array}$ & $\begin{array}{lrl}2 \cdot 6 \mathrm{~cm} . & 1 & \text { hr. } \\
3.0 \mathrm{~cm} . & 14 & \text { hrs. } \\
3.3 \mathrm{~cm} . & 17 & \text { hrs. } \\
3.1 \mathrm{~cm} . & 25 & \text { hrs. } \\
2.8 \mathrm{~cm} . & 4 & \text { days. } \\
2.6 \mathrm{~cm} . & 4 & \text { days. } \\
2.3 \mathrm{~cm} . & \text { Not dis. } \\
2.5 \mathrm{~cm} . & , \\
1.8 \mathrm{~cm} . & , \\
2.5 \mathrm{~cm} . & , \\
2.2 \mathrm{~cm} . & , \\
2.3 \mathrm{~cm} . & ,\end{array}$ & 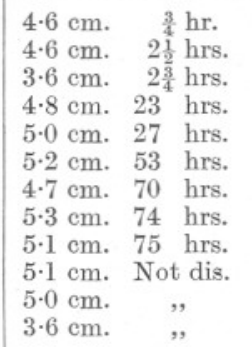 & 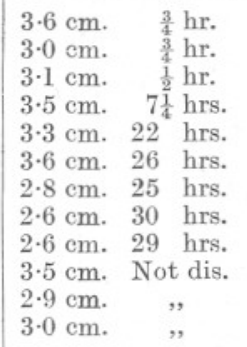 \\
\hline
\end{tabular}

at least as rapidly as the head is dissolved away by the fluid in the stomach. If, for any reason, the vital activities of the animal are reduced, then the style will be softened and finally dissolved.

This explanation will account for all the known facts. When animals are kept out of water, or under anaerobic conditions, or elamped, or for any other reason are in bad condition, their vital activities will be reduced, one result being that secretion of the style will either be greatly diminished or cease altogether. Wherever the style lies in a separate cæcum it will be protected from the action of the fluid in the stomach, so that at most only its head will be dissolved away. Edmondson (4) found that Mya can live for two weeks out of water, and that at the end of that period only the head of the style shows any sign of dissolution.

The style is dissolved when the animal experiences anaerobic conditions not, as Berkeley suggests, especially to set free the oxidase it 
contains, but because of the diminution in the secretion of the style substance. (Incidently, I may say that, by testing with tincture of guiacum and pyrogallol, I have found an oxidase in the styles of all four species.) Moreover, if the oxidase was of the great importance which Berkeley suggests, surely the style would be larger and more readily dissolved in animals which are liable to experience anaerobic conditions, e.g. Mytilus or Mya, than in those, like Pecten, which are never exposed to these conditions. There is no such correlation; the setting free of the oxidase is one of the consequences, not the cause, of the dissolution of the style.

The style never disappears during starvation so long as the animals are kept healthy and the water well aerated. Orton (11) and Berkeley both found this, and I have myself kept twenty-four Mytilus for three weeks in filtered sea water, through which a stream of air was passed, and found styles in all of them at the end of that period. On the other hand, animals which have an ample supply of food, but are in poor condition, have either no style or else only slight traces. Orton states that " . . . oysters in a weak condition are either without a style or very soon lose it on being taken out of water and reform it with difficulty on being replaced in water." This is exactly what would be expected if the rate of secretion of the style is lower in unhealthy, than in healthy, animals.

Under normal conditions, the head of the style will be continually dissolving-which is essential in order that the contained enzymes may be set free-while at the same time the secretion of new substance behind will maintain the style at full size-which is also essential since it must press firmly against the gastric shield upon which it revolves. The style, therefore, is only maintained, and the digestive system can only function properly, as a result of a balance between the rate of its secretion by the style bearing epithelium and the rate of its dissolution by the less acid contents of the stomach.*

\section{Relation Between the pH ot the Gut and the working of its CILIA.}

Gray (5), working on the gill of Mytilus, found that the cilia quickly came to rest in solutions the $\mathrm{pH}$ of which was below about $6 \cdot 0$. Now, since the cilia of the stomach, style sac, and possibly of the mid-gut in all the Lamellibranchs here studied, must normally function in a $\mathrm{pH}$

* Martin (1923, Bot. Gaz., LXXV, p. 143) in a paper on the food of the oyster: states that "The development of a crystalline style is usually correlated with the taking of food, but this structure may appear in the complete absence of food, possibly as a response to the act of siphoning." Since only healthy animals siphon vigorously, this statement fits in perfectly with my findings. 


\section{TABLE VII.}

$\mathrm{A}=$ Cilia active. $\quad \mathrm{F}=$ Cilia feeble. $\quad \mathrm{S}=$ Cilia stopped.

\section{Mya. Gill. $\quad$ Esophagus.}

\begin{tabular}{|c|c|c|c|c|c|c|c|c|c|c|c|}
\hline \multirow{3}{*}{$\begin{array}{c}\text { Initia } \\
\text { pH. } \\
9 \cdot 4\end{array}$} & \multicolumn{5}{|c|}{$\begin{array}{l}\text { Mya. Gill. } \\
\text { Ciliary movement after :- }\end{array}$} & \multicolumn{5}{|c|}{$\begin{array}{l}\text { Esophagus. } \\
\text { Ciliary movement after :- }\end{array}$} & \multirow{2}{*}{$\begin{array}{l}\text { Final } \\
\text { pH. }\end{array}$} \\
\hline & $\frac{1}{2} \mathrm{hr}$ & $1 \mathrm{hr}$. & $3 \mathrm{hr}$. & $6 \mathrm{hr}$. & $22 \mathrm{hr}$. & $\frac{1}{2} \mathrm{hr}$ & $1 \mathrm{hr}$. & $3 \mathrm{hr}$. & $6 \mathrm{hr}$. & $22 \mathrm{hr}$. & \\
\hline & A & A & A & A & A & A & A & A & A & $\mathrm{A}$ & R \\
\hline $7 \cdot 8$ & A & A & A & A & A & A & A & A & A & A & $7 \cdot 8$ \\
\hline $6 \cdot 0$ & A & A & A & A & A & A & A & A & A & A & $7 \cdot 2$ \\
\hline $5 \cdot 2$ & $\mathrm{~S}$ & $\mathrm{~S}$ & $\mathrm{~F}$ & $\mathrm{~F}$ & $\mathrm{~F}$ & A & A & A & A & A & $5 \cdot 8$ \\
\hline $4 \cdot 8$ & $\mathrm{~S}$ & $\mathrm{~S}$ & S & $\mathrm{F}$ & $\mathrm{F}$ & A & A & A & A & A & $5 \cdot 8$ \\
\hline $4 \cdot 4$ & $\mathrm{~S}$ & $\mathrm{~S}$ & $\mathrm{~S}$ & $\mathrm{~S}$ & S & $\mathrm{F}$ & $\mathrm{F}$ & F & F & S & $4 \cdot 4$ \\
\hline $4 \cdot 0$ & $\mathrm{~S}$ & $\mathrm{~S}$ & S & S & S & $\mathrm{F}$ & $\mathrm{F}$ & $\mathrm{F}$ & $\mathrm{F}$ & $\mathrm{S}$ & $4 \cdot 0$ \\
\hline 3.5 & $\mathrm{~S}$ & $\mathrm{~S}$ & $\mathrm{~S}$ & $\mathrm{~S}$ & $\mathrm{~S}$ & $\mathrm{~S}$ & $S$ & S & $\mathrm{S}$ & S & 3.5 \\
\hline $3 \cdot 0$ & $\mathrm{~S}$ & $\mathrm{~S}$ & $\mathrm{~S}$ & $\mathrm{~S}$ & $\mathrm{~S}$ & S & $S$ & S & $\mathrm{S}$ & S & $3 \cdot 0$ \\
\hline
\end{tabular}

\begin{tabular}{c||c|} 
Stomach. & Style Sac. \\
Initial . Ciliary movement after :- & Ciliary movement after :-
\end{tabular}

\begin{tabular}{c||cc} 
Stomach. & Style Sac. \\
Initial . Ciliary movement after :- & Ciliary movement after :- & Final
\end{tabular} pH. $\frac{1}{2}$ hr. $1 \mathrm{hr} . \quad 3 \mathrm{hr} .6 \mathrm{hr} .22 \mathrm{hr} . \quad \frac{1}{2} \mathrm{hr} .1 \mathrm{hr} .3 \mathrm{hr} .6 \mathrm{hr} .22 \mathrm{hr} . \quad \mathrm{pH}$. \begin{tabular}{llllll|llllll}
9.4 & A & A & A & A & A & A & A & A & A & A & 8.8
\end{tabular}

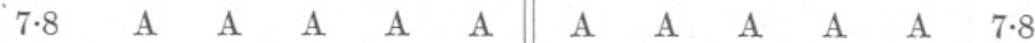
\begin{tabular}{llllll|llllll}
$6 \cdot 0$ & A & A & A & A & A & A & A & A & A & A & $7 \cdot 2$
\end{tabular} \begin{tabular}{llllll|llllll}
$5 \cdot 2$ & A & A & A & A & A & A & A & A & A & A & $5 \cdot 8$
\end{tabular} \begin{tabular}{llllll|llllll}
$4 \cdot 8$ & A & A & A & A & A & A & A & A & A & A & $5 \cdot 8$
\end{tabular} \begin{tabular}{llllll|llllll}
$4 \cdot 4$ & A & A & A & A & A & A & A & A & A & A & $4 \cdot 4$
\end{tabular} $\begin{array}{llllllllllll}4.0 & \text { A } & \text { A } & \text { A } & \text { A } & \text { F } & \text { A } & \text { A } & \text { A } & \text { A } & \text { A } & 4.0\end{array}$ \begin{tabular}{llllll|llllll}
3.5 & $\mathrm{~S}$ & $\mathrm{~S}$ & $\mathrm{~S}$ & $\mathrm{~S}$ & $\mathrm{~S}$ & $\mathrm{~A}$ & $\mathrm{~A}$ & $\mathrm{~F}$ & $\mathrm{~S}$ & $\mathrm{~S}$ & 3.5
\end{tabular}

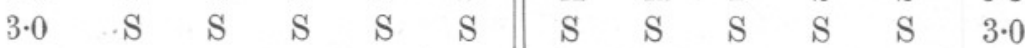

\begin{tabular}{|c|c|c|c|c|c|c|c|c|c|c|c|}
\hline \multirow{2}{*}{$\begin{array}{c}\text { Initial } \\
\mathrm{pH} . \\
9 \cdot 4\end{array}$} & \multicolumn{5}{|c|}{$\begin{array}{l}\text { Mid-Gut. } \\
\text { Ciliary movement after : }\end{array}$} & \multicolumn{5}{|c|}{$\begin{array}{l}\text { Rectum. } \\
\text { Ciliary movement after :- }\end{array}$} & \multirow{2}{*}{$\begin{array}{l}\text { Final } \\
\mathrm{pH} . \\
8 \cdot 8\end{array}$} \\
\hline & $\begin{array}{c}\frac{1}{2} \mathrm{hr} . \\
\mathrm{A}\end{array}$ & $\begin{array}{c}1 \mathrm{hr} . \\
\mathrm{A}\end{array}$ & $3 \mathrm{hr}$. & $\begin{array}{c}6 \mathrm{hr} . \\
\mathrm{A}\end{array}$ & $\begin{array}{c}22 \mathrm{hr} . \\
\mathrm{A}\end{array}$ & $\begin{array}{c}\frac{1}{2} \mathrm{hr} . \\
\mathrm{A}\end{array}$ & $1 \mathrm{hr}$ & $\begin{array}{c}3 \mathrm{hr} . \\
\mathrm{A}\end{array}$ & $\begin{array}{c}6 \mathrm{hr} . \\
\mathrm{A}\end{array}$ & $22 \mathrm{hr}$. & \\
\hline $7 \cdot 8$ & A & A & A & A & A & A & A & A & A & A & $7 \cdot 8$ \\
\hline $6 \cdot 0$ & A & A & A & A & A & A & A & A & A & A & $7 \cdot 2$ \\
\hline $5 \cdot 2$ & A & A & A & A & A & A & A & A & A & A & $5 \cdot 8$ \\
\hline $4 \cdot 8$ & A & A & A & A & A & A & A & A & A & A & $5 \cdot 8$ \\
\hline $4 \cdot 4$ & A & A & $\mathrm{F}$ & F & $\mathrm{S}$ & $\mathrm{F}$ & $\mathrm{F}$ & $\mathrm{F}$ & $\mathrm{F}$ & $\mathrm{S}$ & $4 \cdot 4$ \\
\hline $4 \cdot 0$ & A & A & $\mathrm{F}$ & $\mathrm{F}$ & $\mathrm{S}$ & $\mathrm{F}$ & $\mathrm{F}$ & $\mathrm{F}$ & S & $\mathrm{S}$ & $4 \cdot 0$ \\
\hline 3.5 & $\mathrm{~F}$ & $\mathrm{~S}$ & $\mathrm{~S}$ & $\mathrm{~S}$ & S & S & $\mathrm{S}$ & S & S & $\mathrm{S}$ & 3.5 \\
\hline $3 \cdot 0$ & $\mathrm{~S}$ & $S$ & $\mathrm{~S}$ & $\mathrm{~S}$ & $\mathrm{~S}$ & S & $\mathrm{S}$ & S & S & S & $3 \cdot 0$ \\
\hline
\end{tabular}


below this, it follows that they must have a greater tolerance of the presence of hydrogen ions than those of the gills. In order to test this experimentally, small pieces (not more than a few mm. in diameter) of ciliated epithelium were removed from the gill, œsophagus, stomach, style sac, mid-gut and rectum of Mya, and placed altogether in outside sea water (normal $\mathrm{pH} 7 \cdot 8$ ), to which was added the requisite amounts of $\cdot 1 \mathrm{~N} \mathrm{HCl}$ or $\cdot 1 \mathrm{~N} \mathrm{NaOH}$ needed to make up a series of solutions of varying $\mathrm{pH}$. In every case at least 80 c.c. of fluid was employed. The results of these experiments are given in Table VII.

It will be seen that where the cilia function for any length of time in any fluid they tend to bring the $\mathrm{pH}$ back to that of sea water. Thus water of $\mathrm{pH} 9 \cdot 4$ was reduced to 8.8 after twenty-two hours, and that of $4 \cdot 8$ raised to $5 \cdot 8$. It is impossible, therefore, to state at exactly what $\mathrm{pH}$ the cilia can function unless the $\mathrm{pH}$ at the end of the experiment, as well as at the beginning, is determined. In this case comparative results are more important than absolute results, and in Table VIII the six sets of cilia are arranged in order of their tolerance of the presence of hydrogen ions, and opposite each is shown the $\mathrm{pH}$ of the fluid which normally surrounds them.

\section{TABle VIII.}

$\begin{array}{lccc}\text { Cilia from :- } & & \begin{array}{c}\text { Minimum } \mathrm{pH} \text { in which } \\ \text { they can function. }\end{array} & \begin{array}{c}\text { Average } \mathrm{pH} \text { of fluid } \\ \text { normally round them. }\end{array} \\ \text { 1. Style Sac . } & . & 3 \cdot 5-4 \cdot 0 & 4 \cdot 45 \\ \text { 2. Stomach . } & . & 4 \cdot 0 & 5 \cdot 8 \\ \text { 3. Mid-gut . } & . & 4 \cdot 4-4 \cdot 8 & 6 \cdot 2 \\ \text { 4. Esophagus } & . & 4 \cdot 4-4 \cdot 8 & 6 \cdot 6 \\ \text { 5. Rectum . } & . & 4 \cdot 4-4 \cdot 8 & 6 \cdot 9 \\ \text { 6. Gill . } & . & 5 \cdot 2-5 \cdot 8 & 7 \cdot 2\end{array}$

The comparison between the two sets of figures is very striking, and demonstrates clearly that the more acid the medium in which the cilia normally function, the greater is their tolerance of the presence of hydrogen ions. On the other hand, no difference in their tolerance of hydroxyl ions can be discerned, all six working equally well at $\mathrm{pH} 9 \cdot 4$.

\section{GASTROPODA.}

\section{Hydrogen Ion Concentration in the Gut.}

Unlike the Lamellibranchs, the Gastropods are not a homogeneous group with essentially the same method of feeding, and hence the same type of digestive apparatus, throughout. On the contrary, they include species which feed in the most diverse ways, and the consequent modifica- 
tion in the development of the various regions of the alimentary system and its associated glands is very great.

I have investigated the $\mathrm{pH}$ in the gut of five representative types of Gastropods, namely, Crepidula fornicata (Streptoneura : ciliary feeder), Patella vulgata (Streptoneura: herbivorous), Buccinum undatum (Streptoneura: carnivorous), Doris tuberculata (Euthyneura: carnivorous), Aplysia punctata (Euthyneura: herbivorous). The results are shown in Table IX.

\section{TABLE IX.}

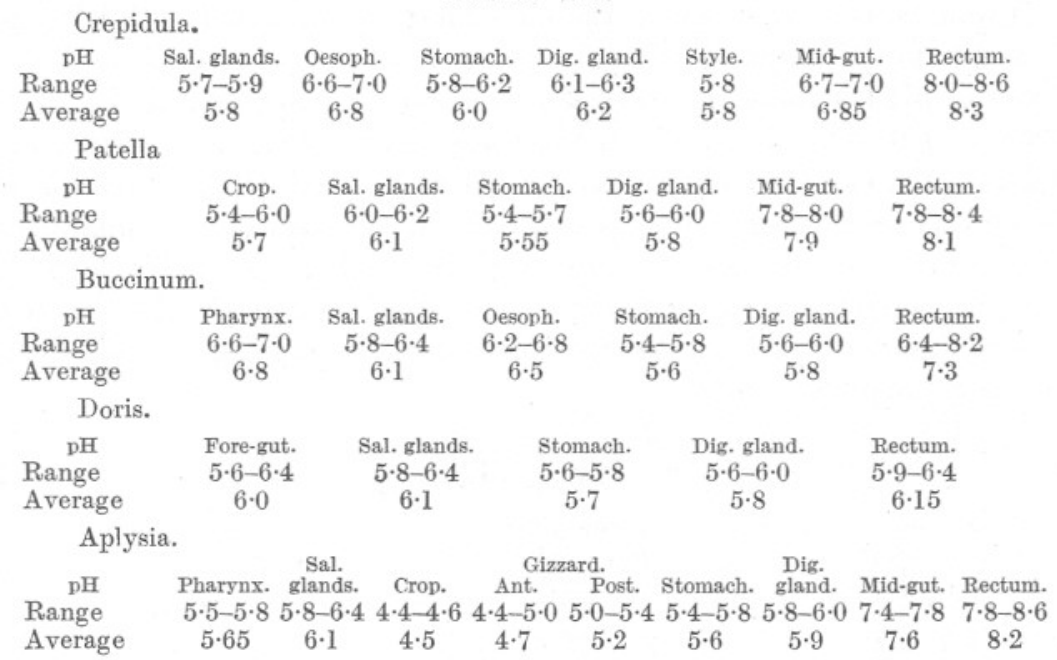

There is a general resemblance between the $\mathrm{pH}$ of the various regions of the gut in the five animals. The $\mathrm{pH}$ of the salivary glands and of the digestive gland is much the same in all, the latter also closely approximating to the $\mathrm{pH}$ of the digestive gland in the Lamellibranchs. The fore-gut or crop and the stomach are invariably the most acid regions of the gut. There are three possible causes of this acidity : (1) The salivary glands. (2) The digestive gland. (3) The style. I will discuss them separately.

1. The Salivary Glands. These are present in all five animals; but in the case of Doris and Aplysia, where the digestive gland possesses secretory cells, they are reduced in size and probably correspondingly reduced in function, while in Crepidula, where the style is well developed, they are also small. In Patella and Buccinum they are large and important glands (in the latter and in all the carnivorous Gastropods belonging to the Streptoneura they secrete a powerful proteolytic enzyme), and, apart from the very feebly developed style in Patella, are responsible for the entire secretion into the gut, and so must be responsible for its acid reaction. 
2. The Digestive Gland. Of the animals studied, only Doris and Aplysia possess secretory cells in the digestive gland. The acid content of the fore-gut may, therefore, have its principal source in the digestive gland, being passed forward from there by an antiperistaltic movement (the fore-gut in these two animals is free and very muscular). The fluid in the crop of Aplysia, especially, is so markedly acid and so plentiful that it seems impossible that the small salivary glands can alone be responsible for it.

3. The Style. Only in Crepidula is there a well-developed style, although Patella possesses the vestige of one. Mackintosh (9) has shown that in its origin, structure and function this style bears the closest resemblance to that of the Lamellibranchs. It does not lie in a separate cæcum, but in a groove in the mid-gut-like the styles of Pecten or Mytilus. It disappears after the animals have been out of water for a day or two, but is reformed when they are returned to sea water, exactly as in Mytilus. As in the Lamellibranchs, it is the most acid substance in the gut ( $\mathrm{pH} 5 \cdot 8)$, and in order to determine to what degree it is responsible for the acid reaction of the stomach, twelve animals were kept out of water for two days and then examined for the condition of the style and the $\mathrm{pH}$ of the stomach; twelve fresh animals were examined at the same time. The two series of results are shown in Table X.

\section{Table $\mathrm{X}$.}

\begin{tabular}{|c|c|c|c|c|}
\hline \multicolumn{3}{|c|}{ Fresh Crepidula. } & \multicolumn{2}{|c|}{ Crepidula out of water 2 days. } \\
\hline $\begin{array}{r}\text { No. } \\
1 .\end{array}$ & $\begin{array}{c}\text { Style. } \\
\text { Present }\end{array}$ & $\begin{array}{c}\mathrm{pH} \text { in Stomach. } \\
6 \cdot 2\end{array}$ & $\begin{array}{l}\text { Style. } \\
\text { Absent }\end{array}$ & $\begin{array}{c}\mathrm{pH} \text { in Stomach } \\
6.8\end{array}$ \\
\hline 2. & ", & $6 \cdot 0$ & , & $7 \cdot 4$ \\
\hline 3. & , & $5 \cdot 8$ & " & $6 \cdot 6$ \\
\hline 4. & , & $6 \cdot 0$ & , & $7 \cdot 2$ \\
\hline 5. & " & $6 \cdot 0$ & $"$ & $6 \cdot 7$ \\
\hline 6. & , & $5 \cdot 8$ & , & $7 \cdot 4$ \\
\hline 7. & , & $5 \cdot 9$ & , & $6 \cdot 9$ \\
\hline 8. & " & $6 \cdot 0$ & " & $7 \cdot 4$ \\
\hline 9. & $"$ & 61 & , & $6 \cdot 8$ \\
\hline 10. & , & $6 \cdot 2$ & " & $7 \cdot 2$ \\
\hline 11. & , & $6 \cdot 1$ & Traces & $7 \cdot 0$ \\
\hline 12. & ", & $5 \cdot 9$ & " & $6 \cdot 9$ \\
\hline & & $g e=\overline{6 \cdot 0}$ & & ge $=\overline{7 \cdot 025}$ \\
\hline
\end{tabular}

As a result of their two days out of water, ten of the animals contained no style and the other two only traces, while the average $\mathrm{pH}$ in the stomach had risen by $1 \cdot 025$. There can be no doubt that, though the 
salivary glands may have some slight effect (though here again a rise in $\mathrm{pH}$ after exposure to the air shows that the presence of $\mathrm{CO}_{2}$ has to be considered), the acid reaction of the gut in Crepidula is primarily due to the dissolution of the head of the style.

The mid-gut and rectum in Crepidula, Patella, Buccinum and Aplysia have all a $\mathrm{pH}$ on the alkaline side. In every case there is a copious secretion of mucus in these regions, and this appears to be responsible for the sudden rise in the $\mathrm{pH}$. In Doris, however, where alone the mid-gut is free from surrounding tissue and has muscular walls so that peristaltic action can easily be observed, little mucus is secreted and, as a result, the $\mathrm{pH}$ is practically the same as that of the stomach and fore-gut.

I have not been able to find any very significant differences between the $\mathrm{pH}$ of the gut in starved animals and those which have been fed. In Aplysia which has been feeding on Ulva, the $\mathrm{pH}$ of the crop and anterior gizzard are raised from 4.5 and $4 \cdot 7$ respectively to $5 \cdot 3$ and $5 \cdot 4$, the result, doubtless, of the dilution of the crop fluid with sea water. A Buccinum whose stomach was full of pieces of squid showed a slight fall in the $\mathrm{pH}$ of the œsophagus, from $6 \cdot 5$ to $6 \cdot 2$. Since Hirsch (8) has shown that in Murex (a closely related species with similar feeding habits and alimentary system) the entrance of food into the gut stimulates the salivary glands to secrete, this fall in $\mathrm{pH}$ in the case of Buccinum may be due to a similar increase in salivary secretion.

\section{Permanence of the Style in Crepidula.}

A similar experiment to that performed on the styles of Mya, Ensis, Pecten and Mytilus was carried out on the styles of Crepidula, by exposing them to solutions of varying $\mathrm{pH}$ and noting the time taken in dissolving. Details of this experiment are given in Table XI.

\section{TABLE XI.}

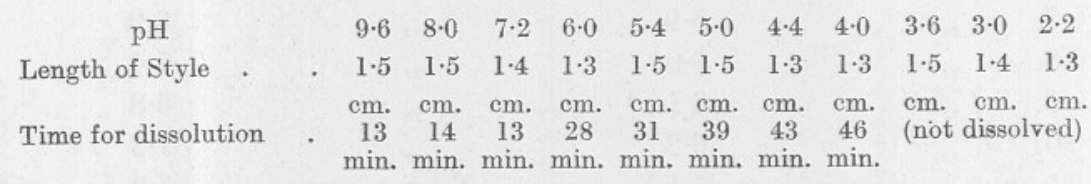

The style of Crepidula resembles those of Pecten and Mytilus in its mode of origin - in a groove off the mid-gut - in its high $\mathrm{pH}(5 \cdot 8)$, as compared with those of Mya and Ensis $(4 \cdot 45$ and $4 \cdot 6)$, and in the lowness of its isoelectric point which is between $3 \cdot 6$ and $4 \cdot 0$. All that has been said about the permanence of the style in Lamellibranchs applies with equal force to the style in the Gastropods. 
Relation between the Cilia and the pH of the Gut.

Experiments similar to those carried out on the ciliated epithelia of the gut of Mya, were performed on the ciliated epithelia of Buccinum and Doris. Although it was found that they will function in a $\mathrm{pH}$ of about $5 \cdot 0$, no very significant differences in their tolerance of hydrogen ions were discovered. Since the range of $\mathrm{pH}$ in the guts of these animals ( 1.7 for Buccinum; 0.45 for Doris) is much less than that in the mantle cavity and gut of Mya (3.0), this is not surprising.

\section{SUMMARY.}

1. In the Lamellibranchs, as typified by Pecten maximus, Mya arenaria and Ensis siliqua, the entire gut has an acid reaction, the stomach being the most acid region and the $\mathrm{pH}$ rising along the mid-gut and rectum.

2. The origin of the acidity of the gut lies in the style. This has a low $\mathrm{pH}(5.4$ in Pecten and Mytilus, 4.6 in Ensis and 4.45 in Mya), and, after it has been artificially extracted from Mya or induced to disappear, by keeping the animals under abnormal conditions, in Mytilus, Tapes and Pecten, the $\mathrm{pH}$ of the stomach invariably rises (by as much as 0.825 in Mya and 0.72 in Tapes), although the $\mathrm{pH}$ in the mantle cavity has fallen.

3. The style, which dissolves rapidly in alkaline or weakly acid media, is not dissolved in fluids below a certain $\mathrm{pH}-4 \cdot 4$ for Ensis, $4 \cdot 2$ for Mya, 3.6 for Pecten and Mytilus.

4. The style is never absent, even though animals are starved, so long as they are kept under otherwise healthy conditions. The disappearance of the style under abnormal conditions is probably due to a lowering of the vital activities, which include the secretion of the style substance, and the consequent dissolution of the style by the less acid contents of the stomach.

5. The style is only maintained as a result of a balance between the rate of its secretion and the rate of its dissolution.

6. There is a well-marked correlation between the tolerance of the presence of hydrogen ions possessed by the cilia from the various regions of the gut and the degree of acidity of the fluid with which they are normally surrounded.

7. The $\mathrm{pH}$ of the gut in five Gastropods has been investigated. The fore-gut and stomach have invariably the lowest $\mathrm{pH}$.

8. This acidity may be caused by the salivary glands (Patella and Buccinum), the digestive gland (Doris and Aplysia), or the style (Crepidula). 
9. The mid-gut and rectum have a high $\mathrm{pH}$, except in Doris, where there is little secretion of mucus, the gut being free and muscular.

10. The style of Crepidula has similar properties to those of the Lamellibranchs. It has a $\mathrm{pH}$ of $5 \cdot 8$, and is not dissolved in fluid of $\mathrm{pH} 3 \cdot 6$ or lower.

11. The cilia from the gut of Buccinum and Doris can function in a $\mathrm{pH}$ of $5 \cdot 0$, but there is little difference in the toleration of the various cilia to the presence of hydrogen ions.

\section{BIBLIOGRAPHY.}

1. Allen, W. R. 1914. The Food and Feeding Habits of Freshwater Mussels. Biol. Bull., XXVII, p. 127.

2. Berkeley, C. 1923. On the Crystalline Style as a possible factor in the Anaerobic Respiration of certain Marine Mollusks. Jour. Exp. Zool., XXXVII, p. 477.

3. Dakin, W. J. 1909. Pecten. L.M.B.C. Memoir, No. XVII.

4. Edmondson, C. H. 1920. The Reformation of the Crystalline Style in Mya arenaria. Jour. Exp. Zool., XXX, p. 259.

5. Gray, J. 1920. The Effects of Ions upon Ciliary Movement. Q.J.M.S., LIV, p. 345.

6. Haseloff, B. 1888. Über den Krystallstiel der Muscheln nach Untersuchung verschiedener Arten der Kieler Bucht. Biol. Centr., VII, p. 683.

7. Hazay, J. 1881. Die Molluskenfauna von Budapest. Malak. Bl. L. Pfeiffer. N.F., IV, p. 195.

8. Hirsch, G. C. 1914. Die Ernährungsbiologie fleischfressender Gastropoden. Zool. Jahr. Abt. Zool. u. Physiol., XXXV, p. 357.

9. Mackintosh, N. A. 1925. The Crystalline Style in Gastropods. Q.J.M.S., LXIX, p. 317.

10. Nelson, T. C. 1918. On the Origin, Nature, and Function of the Crystalline Style of Lamellibranchs. Jour. Morph., XXXI, p. 53.

11. Orton, J. H. 1923. Fishery Investigations. Series II, Vol. VI, No. 3, p. 54 .

12. Yonge, C. M. 1923. The Mechanism of Feeding, Digestion, and Assimilation in the Lamellibranch Mya. Brit. Jour. Exp. Biol., I, p. 15 . 